\title{
Development of the sectoral system of remuneration of medical workers of state healthcare institutions of the constituent entities of the Russian Federation
}

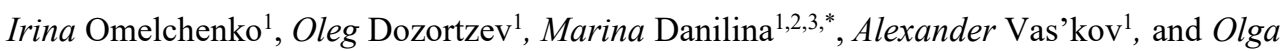 \\ Zabelina $^{1}$ \\ ${ }^{1}$ Research Institute VNII of Labor, Ministry of Labour of Russia, Zemlyanoy Val, 34, 105064 \\ Moscow, Russia \\ ${ }^{2}$ Finance University under the Government of the Russian Federation, Leningradsky prosp., 49, \\ 125993 Moscow, Russia \\ ${ }^{3}$ Russian Economic University, Stremyanny per., 36, 117997 Moscow, Russia
}

\begin{abstract}
The article analyses the Development of a sectoral system of remuneration of medical workers of state healthcare institutions of the constituent entities of the Russian Federation. It was determined, the PM differentiation, as well as the differentiation of the cost of a fixed set of consumer goods and services, is too low for use in the OSS, while the value of the coefficient of variation for the median wage is much higher, and at the same time, if this indicator is used in the OSS, with a significant decrease in the differentiation between the most the richest and poorest budgets will not experience the problems. Thus, the most appropriate indicator, taking into account the existing resources of the federal budget, for use in order to take into account the economic differentiation of a constituent entity of the Russian Federation is the median salary of employees of organizations.
\end{abstract}

\section{Introduction}

The determination of the minimum tariff rate (minimum salary) is the central point for the development of a remuneration system, regardless of the level at which it is supposed to be applied. The minimum wage rate is the rate of payment for the labor standard (standard), having the lowest characteristics for all factors that could form a tariff. The level of remuneration of an employee engaged in such work, provided full performance of his work duties must provide him the consumption level sufficient to reproduce its ability to labor.

The size of the minimum wage rate (official salary) must be at a level not less than the minimum wage, established at the state level. From a scientific point of view, the most justified criterion for ensuring the share of salaries in the wage structure at a level of at least $50 \%$, according to the Unified Recommendations, it is advisable to preserve the use of the PCG (modified taking into account the current labor functions of medical workers), but with

\footnotetext{
*Corresponding author: marinadanilina@yandex.ru
} 
the use of basic minimum salaries, the establishment of which is enshrined in Article 144 of the Labor Code of the Russian Federation, while linking the size of the minimum wage of a worker of the 1 st category to the size of the value of the concept of "minimum consumer budget".

\section{Materials and methods}

To date, there are no guidelines for setting salaries in budgetary institutions, with the exception of the minimum wage, which is equal to the subsistence minimum, but is not mandatory in terms of setting minimum salaries. In turn, the PM is formed on the basis of the consumer basket and reflects the value of the minimum set of food products, non-food goods and services, as well as mandatory payments and fees, necessary to preserve human health and ensure his life.

At the same time, the minimum permissible level of satisfaction of the material and spiritual needs of a person employed in labor, as well as the basic value and structure of consumption of goods and services necessary for a person for normal life, are more accurately and reasonably characterized by the concept of "minimum consumer budget".

The consumer budget is a broad concept that characterizes the structure and balance of incomes and expenses of people (families and single people, employed and unemployed, etc.), as well as the structure of needs that determines the directions of using income for the purchase of various goods and services, for investments, savings and other purposes.

The consumer budget expresses the value of a set of food and non-food goods and services. Consumer budgets differ in the degree to which basic physiological social and spiritual needs are met. The expenditure side of the consumer budget is determined by the following factors:

1. Physiological needs of people (biological factor).

2. Type and nature of work (professional factor).

3. The level of cultural development of a person (general cultural factor).

4. Working conditions: the level of mechanization, automation, hygienic conditions, working hours and rest (production factor).

5. Habitual lifestyle and standard of living (socio-historical factor).

6. Age composition of the family (demographic factor).

7. Natural and climatic conditions (geographic factor).

8. National customs (ethnic factor).

9. Intentions and moods of people (psychological factor).

There are a large number of combinations of the above factors that determine the needs and form consumer budgets for various categories of people. At the same time, the minimum consumer budget is one of the main system-forming basic budgets (along with the subsistence minimum). The minimum consumer budget is a criterion for a socially acceptable level of reproductive consumption (calculated at the lowest level of welfare).

Taking into consideration the fact that the level of wages should contribute to the reproduction of the labor force and correspond to the cost estimate of the restoration of the ability to work, the sociocultural needs of a person, it is the minimum consumer budget that should be used as the base salary (official salary). An example of the formation of the structure and calculation of the cost of the minimum consumer budget of a man of working age engaged in light physical labor (with a minimum level of labor complexity) is presented in the previous report on the research work "Development and scientific substantiation of proposals to improve wage systems ...". The cost of the consumer budget in March 2019 prices amounted to 13,432.51 rubles, which exceeds the minimum wage set as of 01.01.2020.

Another scientifically grounded approach to setting the minimum wage rate is to determine the ratio of the minimum consumer wage relative to the average wage for the 
relevant period. If this ratio is at a level exceeding $45-50 \%$, then the corresponding value cannot be taken as the minimum tariff rate, since there will be no funds left for normal differentiation by other tariff-forming factors (complexity, working conditions), as well as for incentives for over-fulfillment of norms labor costs and bonus indicators. If this ratio is in the range of $35-45 \%$, then this calculated value can be taken as the minimum tariff rate.

In practice, taking into consideration the tight deadlines and the lack of flexibility of domestic legislation, it was decided to accept the minimum wage as of 01/01/2020 as the minimum value that can correspond to the minimum wage rate (salary). The use of the minimum wage, taking into consideration the complete reduction of its separation from the minimum necessary physiological conditions for the reproduction of labor (PM), can be considered a reasonable decision, but not optimal.

At the same time, the OSS takes into consideration the differentiation in the size of wages in the constituent entities of the Russian Federation due to the application of the coefficient of regional economic differentiation. The second no less complex and difficult task in the development of a wage system is to determine the composition of tariff-forming factors, their relationships with each other and the principles of differentiation of tariff payment.

Taking into consideration a wide range of compensation and incentive payments, taking into consideration the impact on wages of various working conditions, including the establishment of compensations for the negative impact of unfavorable environmental conditions on the body of workers, the main tariff-forming factor will be the complexity of labor. The complexity of labor, expressed both in the direct physiological zeal of the employee and in the qualification requirements for the work performed, as well as, in general, labor functions are described in detail in professional standards, and the differentiation by levels of complexity is reflected when the positions of medical workers are divided according to the PCG.

Taking into consideration the large number of meetings of the working group on the development of the OSHP, which includes specialized experts from the Ministry of Health of the Russian Federation, expressing their opinion on the complexity of work (in particular, on the level of responsibility in certain positions), it was decided to update the existing CAP in order to form more objective differentiation by the complexity of job positions. The PKG "Medical and pharmaceutical personnel of the first level" (2 qualification levels), "Nursing and pharmaceutical personnel" (6 qualification levels), "Doctors and pharmacists" (6 qualification levels) were expanded. The number of qualification levels in the PCG "Heads of structural units of institutions with higher medical and pharmaceutical education (specialist doctor, pharmacist)" has not been changed.

Taking into account the complexity coefficients agreed with the experts of the Ministry of Health of the Russian Federation during the development of the model, reflecting fair differentiation in the remuneration of medical workers, the most relevant grid of complexity coefficients for use in OHS when excluding qualification categories from salaries is the UTS dated 01.12.2001, which has 18 digits and the ratio of the 18th to the first digit is $4.5: 1$. Taking into account the fact that in the new PCG (developed by the Ministry of Health of Russia and the Ministry of Labor of Russia) differentiation by 16 qualification levels is used, it seems justified to use the first 16 categories of the proposed UTS, taking into account the decrease in coefficients in proportion to a certain influence on the complexity of labor of qualification categories to the value " no category ".

\section{Results and discussions}

The most controversial issue in the course of determining the complexity coefficients, reflecting the differentiation between the qualification levels of medical workers, was the question of including the complexity coefficients of qualification categories in the grid. On 
the one hand, employees who confirm the category can perform more complex work, on the other hand, all the work that employees must perform in one position, regardless of the qualification category, are described in job descriptions. Thus, it is not clear how the confirmation of the qualification category affects the complexity and quality of the services provided by health workers.

If the accounting of qualification categories is included in the coefficient grid, it is necessary to revise and update absolutely all job descriptions, which should reflect the specific duties that the employee must perform, taking into consideration the confirmation of a particular qualification category. As a result, it was decided not to include qualification category coefficients in the grid.

A distinctive feature of the post-Soviet period of development of the economic system of the Russian Federation is an extremely high degree of stratification of the constituent entities of the Russian Federation according to the socio-economic level of development, which is expressed in all aspects of society, including wages. In the Russian Federation, there is a high differentiation of wages, and it is impossible not to take into consideration the economic component when determining the fair amount of wages, since the purchasing power of money in the constituent entities differs significantly. In this regard, as well as taking into consideration the need to reduce the differentiation of wages of medical workers in different constituent entities of the Russian Federation, when developing an OSHP, it is necessary to reasonably take into consideration economic differentiation.

For this purpose, it is proposed to take into consideration economic differentiation when calculating the official salary of medical workers using the concept of "coefficient of regional economic differentiation".

The basis for determining this coefficient at various stages of the study of the problem was:

- the cost of a fixed set of consumer goods and services;

- living wage;

- average monthly accrued wages of employees of organizations;

- average monthly accrued wages of employees in organizations, individual entrepreneurs and individuals (hereinafter - ZNR);

- the median value of the accrued wages of employees of organizations.

For interregional comparisons of the purchasing power of the population in the Russian Federation and individual constituent entities of the Russian Federation, the cost of a fixed set of consumer goods and services is calculated on the basis of consumption volumes that are uniform for all constituent entities of the Russian Federation, as well as regional average prices. The set includes 83 items of goods and services, including 30 types of food products, 41 types of non-food products and 12 types of services. The cost of the set is given per month.

Taking into account the task of objectively assessing economic differentiation in the OSS, the cost of a fixed set is the most appropriate indicator for the formation of official salaries.

However, the financial capabilities of the state cannot provide such a rapid reduction in the gap between the wages of workers in various constituent entities of the Russian Federation, the consequences of using this indicator in determining official salaries will lead to very high costs for OSH, to an imbalance in the labor market in the public sector, to protest moods of employees of state and municipal organizations in other social spheres.

Therefore, as a basis for determining the coefficient of regional economic differentiation, alternative options were proposed, assessed by the coefficient of variation of the sample (for the constituent entities of the Russian Federation).

Preparation of proposals for the formation of lists and conditions for the establishment of compensation and simulation payments.

For a number of compensatory and incentive payments, the amounts and conditions for implementation are determined by the Labor Code of the Russian Federation and decrees of 
the Government of the Russian Federation (payments for regional regulation of wages, bonuses for detecting oncological diseases and payments for birth certificates, etc.). For the rest, it is proposed to establish the size and conditions of implementation separately by the Government Decree.

In accordance with Article 147 of the Labor Code of the Russian Federation, the minimum wage increase for employees engaged in work with harmful and (or) hazardous working conditions is $4 \%$ of the tariff rate (salary) established for various types of work with normal working conditions. It is proposed to establish the amount of additional payments depending on the class of labor conditions from 4 to $12 \%(3.1-4 \% ; 3.2-6 \% ; 3.3-8 \% ; 3.4-10 ; 4-$ $12 \%$ ), which will ensure optimal differentiation of these payments by degrees of hazard.

In accordance with the Law of the Russian Federation of July 2, 1992 No. 3185-1 "On psychiatric care and guarantees of the rights of citizens in its provision", Federal Law of June 18, 2001 No. 77-FZ "On the prevention of the spread of tuberculosis in the Russian Federation" [49] and Federal Law of March 30, 1995 No. 38-FZ "On the prevention of the spread in the Russian Federation of a disease caused by the human immunodeficiency virus (HIV)", the order and size of an increase in wages for work with harmful and (or) dangerous working conditions for medical workers of state institutions of the constituent entities of the Russian Federation involved in the provision of psychiatric care, directly involved in the provision of anti-tuberculosis care, carrying out diagnostics and treatment of HIV-infected, as well as persons, whose work is related to materials containing the human immunodeficiency virus are established in the manner determined by the executive authorities of the constituent entities of the Russian Federation.

In order to unify the approaches to the establishment of these compensation payments, the Project proposes the establishment of uniform amounts of compensation payments to medical workers directly involved in the provision of anti-tuberculosis care in the amount of 40\%; medical workers who diagnose and treat HIV-infected people, and persons whose work is associated with materials containing the human immunodeficiency virus in the amount of $60 \%$; medical professionals involved in the provision of mental health care $30 \%$.

In accordance with Article 154 of the Labor Code of the Russian Federation, the increase in wages for night work is established by collective agreements, but not lower than the minimum amount established by the Government of the Russian Federation.

According to the Decree of the Government of the Russian Federation No. 554 of July 22,2008 , the minimum wage increase for night work is 20 percent of the hourly wage rate (salary (official salary) for each hour of night work).

At the same time, in a number of regions, in the remuneration systems introduced after 2005 , the rates of increase in the payment for hours of night work of medical workers, previously established within the framework of regional tariff scales, were retained $-50 \%$.

In this connection, it is proposed to establish a single general requirement for compensation payments in all regions for work at night in the amount of $50 \%$ of the official salary calculated per hour of work.

It is also proposed to include in the list of incentive payments a supplement for work in an ambulance in the amount of - 50\%, in the same amount to establish extra charges to the hourly rates of consultant doctors (specialist doctors) attracted from other institutions; an allowance for medical specialists for medical care provided on an outpatient basis in the amount of $30 \%$ and an allowance for medical workers of feldsher-obstetric points (heads of feldsher-obstetric points, feldshers, obstetricians (midwives), nurses, including nursing nurses) for the provided medical care on an outpatient basis in the amount of $30 \%$; allowances for the precinct: to district doctors - district therapists, district pediatricians, general practice doctors (family doctors), district nurses, district therapists, district pediatricians and nurses of general practitioners (family doctors) for medical care provided on an outpatient basis at a rate of $40 \%$; bonus for work in mobile teams. 
These payments are offered instead of previously paid within the framework of the national project "Health", as well as in exchange for payments for work experience or seniority.

In accordance with article 105 of the Labor Code of the Russian Federation, in those jobs where it is necessary due to the special nature of work, as well as in the production of work, the intensity of which is not the same during the working day (shift), the working day can be divided into parts so that the total the duration of the working time did not exceed the established duration of the daily work.

In order to unify payments for the allowance for dividing the working day into parts, it is proposed to establish a single amount of the said allowance at a rate of $30 \%$.

At present, in most regions, payments are made "bonus for work in rural areas" in the amount of $25 \%$. It is envisaged to preserve it in the systems of remuneration of employees of institutions, since it is important for attracting qualified medical personnel to the village.

Incentive payments in the form of bonuses for work in hospitals for war veterans and bonuses for work in children's homes are established in the current remuneration systems of the regions. In connection with the social significance of the institutions, it is also envisaged to preserve the specified payment in the amount established in the existing systems of remuneration of labor in the regions.

The payment for mentoring evaluates the contribution of specialists to the accelerated development of practical skills of young specialists, as well as their professional adaptation, consolidation and development of professional skills among young specialists. Improving the efficiency of employment of graduates who have passed the accreditation of specialists, including those who have completed targeted training. In this connection, it is proposed to establish the specified mark-up at a rate of $15 \%$.

It is proposed to establish the remuneration based on the results of work according to indicators and criteria at a minimum amount (10\%) in order to exclude employers' abuse in the appointment of these payments and to establish the transparency of their calculation.

\section{Conclusion}

As it was determined, the PM differentiation, as well as the differentiation of the cost of a fixed set of consumer goods and services, is too low for use in the OSS, while the value of the coefficient of variation for the median wage is much higher, and at the same time, if this indicator is used in the OSS, with a significant decrease in the differentiation between the most the richest and poorest budgets will not experience the problems described above.

Thus, the most appropriate indicator, taking into account the existing resources of the federal budget, for use in order to take into account the economic differentiation of a constituent entity of the Russian Federation is the median salary of employees of organizations.

\section{References}

1. Allegretto, Sylvia, Arindrajit Dube, Michael Reich, and Ben Zipperer, Credible Research Designs for Minimum Wage Studies (Working paper, Institute for Research on Labor and Employment, UC Berkeley, 2013)

2. P. Bastos, N. Monteiro, Journal of Economics and Management Strategy, 20(4), 957 (2011)

3. Belman, Dale and Paul Wolfson, What Does the Minimum Wage Do? (Kalamazoo, MI: W.E. Upjohn Institute for Employment Research, 2014) 
4. Belser, Patrick and Uma Rani, Minimum Wages and Inequality, Janine Berg (Ed.) Labour Markets, Institutions and Inequality: Building Just Societies in the 21st Century (Edward Elgar Publishing, Cheltenham, UK, 2015)

5. V. Gimpelson, R. Kapelyushnikov, A. Lukyanova, Comparative Economic Studies, 52(4), 611 (2010)

6. S. Kapelyuk, Economics of Transition, 23(2), 389 (2015)

7. A. Lukiyanova, N. Vishnevskaya, The Decentralization of Minimum Wage Setting in Russia. Working papers by NRU Higher School of Economics. Series WP BRP "Economics/EC", 90 (2015)

8. A. Muravyev, Europe-Asia Studies, 66(8), 1270 (2014) 